\title{
Genetic improvement of plant architecture in the common bean
}

\author{
V.M.P. Silva ${ }^{1}$, J.A.N. Menezes Júnior ${ }^{1}$, P.C.S. Carneiro ${ }^{2}$, J.E.S. Carneiro ${ }^{3}$ \\ and C.D. Cruz ${ }^{2}$
}

1'Área de Melhoramento Genético, Instituto Agronômico do Paraná, Londrina, PR, Brasil

${ }^{2}$ Departamento de Biologia Geral, Universidade Federal de Viçosa, Viçosa, MG, Brasil

${ }^{3}$ Departamento de Fitotecnia, Universidade Federal de Viçosa,

Viçosa, MG, Brasil

Corresponding author: V.M.P. Silva

E-mail: vanessa@iapar.br

Genet. Mol. Res. 12 (3): 3093-3102 (2013)

Received April 22, 2012

Accepted October 20, 2012

Published January 30, 2013

DOI http://dx.doi.org/10.4238/2013.January.30.8

\begin{abstract}
Knowledge of genetic control of plant architecture in the common bean can help breeders define the most adequate breeding strategy to optimize gains. We examined genetic control of plant architecture in the common bean by means of partial diallel crosses. Fourteen bean lines were crossed under a partial diallel scheme, in which group 1 was composed of 8 erect plant lines and group 2 of 6 cariocatype grain lines. The $\mathrm{F}_{1}$ plants from the crosses and the 14 parents were evaluated during spring (March sowing) for the characteristics plant architecture score, hypocotyl diameter, mean plant height, and grain yield. The additive effects were found to predominate in the genetic control of plant architecture score and hypocotyl diameter. Thus, selection of more erect plants can be done in early generations. Heritability estimate in a wide sense was greater for hypocotyl diameter $(0.81)$ than for plant architecture score (0.60), showing that the latter is a more complex characteristic than the former. Hypocotyl diameter has
\end{abstract}


the potential to be used in the selection of more erect plants, either by considering selection between and within families, or by combined or phenotypic recurrent selection. The reason for this is that the diameter measurements are taken from individual plants inside the plots.

Key words: Phaseolus vulgaris L.; Genetic control; Plant architecture; Partial diallel; Quantitative genetics

\section{INTRODUCTION}

The common bean is no longer a subsistence culture and has undergone great changes, especially with the adoption of new technologies, such as irrigation and mechanized harvest. To meet the demands of farmers from irrigated areas, common bean breeders have sought the selection of erect plants (Silva et al., 2009). Besides facilitating mechanized harvest and cultivation practices, erect plant cultivars help reduce the incidence of some diseases, such as white mold, and minimize the harvest damages during prolonged rainfall.

Selecting erect plants is a challenging task, since there are many traits that make up the architecture of the plant which may influence character expression. Common bean plant architecture has attracted the attention of breeders, who have tried to find an ideotype (Adams, 1973, 1982; Kelly and Adams, 1987; Brothers and Kelly, 1993; Beattie et al., 2003; Silva et al., 2009).

Some morphological traits, such as plant height, internode number and length, hypocotyl diameter and length, number of pods on top, middle and bottom third of the stem, first pod insertion height, and number of pods on the main stem, are part of the major studies aimed at identifying the traits that best define the plant architecture of the common bean (Izquierdo and Hosfield, 1983; Nienhuis and Singh, 1986; Acquaah et al., 1991, 1992; Kornegay et al., 1992; Brothers and Kelly, 1993). Plant height, hypocotyl diameter, pod distribution in the plant's midsection, and branch insertion angle have been given special consideration (Acquaah et al., 1991, 1992).

Understanding the genetic effects in the control of plant architecture in the common bean can help breeders define the most adequate breeding strategy aimed at optimizing selection gain. Information in the literature on genetic control of plant architecture in the common bean is still scarce. There is evidence that several genes may be involved and that environment has a great influence on character expression (Teixeira et al., 1999; Bassett, 2004; Moreto et al., 2007).

One of the most accurate genetic designs to obtain information on the genetic control of characters is the diallel cross design, with emphasis on the method of Hayman (1954), since it allows inferring the basic inheritance mechanism of the character under study. This method allows diallel analysis of the $\mathrm{F}_{1}$ and/or $\mathrm{F}_{2}$ generations obtained from the crosses involving homozygotic parents (Cruz et al., 2004).

In common bean breeding programs, there is not always interest in evaluating all possible combinations of a complete diallel, mainly due to the difficulty in obtaining a sufficient number of hybrid seeds and the interest in combining characters present in distinct parents. Thus, the use of partial diallel crosses has become a promising alternative, as it allows studying the inheritance of one or more of the characters in question, as well as choosing the segregating populations with the highest potential for the extraction of superior lines. The adaptation of the method proposed by Hayman (1954) for partial diallel crosses was developed by Viana et al. (1999). However, there are no reports in the literature using this method in the 
common bean crop, aimed at the inheritance of characters related to plant architecture.

Thus, this study was carried out to obtain estimates of the genetic effects in the control of plant architecture of the common bean by means of partial diallel crosses.

\section{MATERIAL AND METHODS}

Fourteen common bean lines (Table 1) were crossed under a partial diallel cross scheme. These lines were divided into two divergent groups, considering the plant's architecture, yield, and grain type. Group 1 was composed of 8 lines, 3 black grain and erect plants (BRS Valente, BRS Supremo, and IPR Uirapuru), 3 carioca-type grain and also erect plants (BRS Horizonte, CNFC 9466, and A805), but showing poor yield and/or grain type, and 2 erect plant lines of mulatinho grain type (A170 and A525). Group 2 was composed of 6 carioca-type grain lines, with 3 originating from crosses with isoline Rudá-R (Ragagnin et al., 2009), a source of different genes resistant to anthracnose, angular spot, and rust (UTF 0013 x Rudá-R, GEN 12-2 x Rudá-R, and CNFC 9437 x Rudá-R), herein denominated L1, L2, and L3, respectively, and lines VC6, BRS MG Majestoso, and Madrepérola. Group 2 lines produce grains with good yield performance and commercial aspect, but inferior plant architecture.

\begin{tabular}{lllll}
\multicolumn{5}{c}{ Tabela 1. Origin, grain type, plant type, and plant architecture of 14 bean lines used in diallel crosses. } \\
\hline Parent & Origin & Grain type & Plant type & Plant architecture \\
\hline BRS Valente & Embrapa & Black & II & Erect \\
BRS Supremo & Embrapa & Black & II & Erect \\
IPR Uirapuru & IAPAR & Black & II & Erect \\
BRS Horizonte & Embrapa & Carioca & II & Erect \\
CNFC 9466 & Embrapa & Carioca & II & Erect \\
A805 & CIAT & Carioca & II & Erect \\
A170 & CIAT & Mulatinho & II & Erect \\
A525 & CIAT & Mulatinho & II/III & Semi-prostrate \\
VC6 & UFV & Carioca & II/III & Semi-prostrate \\
BRS MG Majestoso & Convênio & III & II/III & Prostrate \\
Madrepérola & UFV & Carioca & III & Pemi-prostrate \\
L1 & UFV & Carioca & III & Prostrate \\
L2 & UFV & Carioca & Carioca & UFV \\
L3 & UFV & & & \\
\hline
\end{tabular}

${ }^{a}$ The 8 first parents constitute group 1 and the others, group 2, for the diallel crosses. ${ }^{b}$ Agreement UFLA/UFV/ EPAMIG/Embrapa.

The crosses to obtain the hybrid seeds were carried out in a greenhouse, following the procedure without emasculation, as described by Peternelli et al. (2009).

The $\mathrm{F}_{1}$ seeds were sown in the field together with the parents in an experiment consisting of 62 treatments ( 48 hybrids +14 parents). Evaluation was carried out during spring (March sowing) in a randomized block design with three replications. The plots were made up of three lines of $1.4 \mathrm{~m}$, with planting density of 12 seeds per meter and spacing between lines of $0.50 \mathrm{~m}$. The experiment was conducted at an altitude of $690 \mathrm{~m}$ and $20^{\circ} 45^{\prime} \mathrm{S}$ latitude and $42^{\circ} 51^{\prime} \mathrm{W}$ longitude. The cultivation practices adopted were those recommended for the bean crop in the region.

In the field, mean plant height was evaluated in $\mathrm{cm}$, and plant architecture by a grade scale ranging from 1 to 5, according to Collicchio et al. (1997): grade 1 refers to type II plant, 
erect, with a single stem, and high first pod insertion; grade 2, to type II plant, erect, and with some ramifications; grade 3 , to type II or III plant, erect, with many ramifications and tendency for prostrate growth; grade 4, to type III plant, semi-erect, partially prostrate; grade 5, to type III plant, with long internodes and very prostrate.

After harvest, besides grain yield in $\mathrm{kg} / \mathrm{ha}$, some characteristics related to plant architecture were evaluated: hypocotyl diameter $(\mathrm{cm})$, first pod insertion height $(\mathrm{cm})$, number of total pods, number of pods on the branches, and number of branches. These characteristics were measured using 10 plants obtained from the central line of each plot, where the means were used for statistical analysis.

The characteristics hypocotyl diameter, first pod insertion height, number of total pods, number of pods in the branches, number of branches, and mean plant height were correlated with the plant architecture grade to determine the possibility of using them in the selection of plants with more erect architecture.

The data obtained were submitted to analysis of variance. The means of the parents and $F_{1}$ plants were analyzed according to the partial diallel model proposed by Viana et al. (1999), adapted from the Hayman method (1954).

The sufficiency of the dominant-additive model was evaluated by the linear regression coefficient of $\mathrm{W}_{\mathrm{r}}$ as a function of $\mathrm{V}_{\mathrm{r}}($ where $\mathrm{r}=1,2, \ldots, 8)$ for group 1 and of $\mathrm{W}_{\mathrm{s}}$ as a function of $\mathrm{V}_{\mathrm{s}}$ (where $\mathrm{s}=1,2, \ldots, 6$ ) for group 2, where $W_{r}$ is the covariance between the mean of parent $\mathrm{r}$ (group 1) hybrids and the mean of the group 2 parents; $V_{r}$, the variance of the mean of parent $\mathrm{r}$ (group 1) hybrids; $W_{s}$, the covariance between the mean of parent $\mathrm{s}$ (group 2) hybrids and the mean of group 1 parents, and $V_{s}$, the variance of the means of parent s (group 2) hybrids.

For the characters in which sufficiency of the dominant-additive model was observed in the inheritance study, the following genetic and environmental components were estimated: $\mathrm{D}_{(1)}$ and $\mathrm{D}_{(2)}$ : components associated with the additive effects; $\mathrm{H}_{1(1)}, \mathrm{H}_{1(2)}$ and $\mathrm{H}_{2}$ : components associated with the dominance effects; F: component associated with covariance between the additive and non-additive effects; $h^{2}$ : quadratic component determined by the difference of means between hybrids and parents; $\varepsilon$ : environmental variance component.

The significance of each component was tested by $t$ statistics, obtained by the ratio of the estimates of the genetic parameters to their respective standard deviation. Since, the degrees of freedom associated with these statistics are not well established in this case, $t$ values above 1.96 were considered to be significant at 5\% probability, according to Singh and Chaudhary (1979).

The statistical analyses were carried out using the computational resources of the GENES program (Cruz, 2006).

\section{RESULTS AND DISCUSSION}

\section{Sufficiency test of the dominant-additive model}

The traits hypocotyl diameter and mean plant height were the most correlated with plant architecture grade (Table 2), indicating that these traits are the most promising to help in the selection of erect plants. Thus, this study focused only on the traits: plant architecture grade, hypocotyl diameter, mean plant height, and grain yield. 
Table 2. Estimates of the genotypic correlations between plant architecture grade (PAG), mean plant height (MPH), hypocotyl diameter (HD), first pod insertion height (FPIH), number of total pods (TP), number of pods in the branches (PB), number of branches (NB), and grain yield (YIELD) in the common bean.

\begin{tabular}{|c|c|c|c|c|c|c|c|c|}
\hline & PAG & MPH & HD & FPIH & $\mathrm{TP}$ & PB & NB & YIELD \\
\hline$\overline{P A G}$ & - & $-0.791 *$ & $-0.799 *$ & 0.185 & 0.092 & 0.578 & 0.387 & $0.452 *$ \\
\hline MPH & & - & $0.783^{*}$ & -0.157 & 0.213 & -0.285 & $-0.487 *$ & $-0.639^{*}$ \\
\hline HD & & & - & 0.229 & 0.422 & $-0.307^{*}$ & $-0.414 *$ & -0.164 \\
\hline FPIH & & & & - & $0.395^{*}$ & -0.036 & $-0.321 *$ & 0.408 \\
\hline $\mathrm{TP}$ & & & & & - & 0.346 & -0.192 & 0.091 \\
\hline PB & & & & & & - & 0.647 & 0.165 \\
\hline NB & & & & & & & - & 0.279 \\
\hline YIELD & & & & & & & & - \\
\hline
\end{tabular}

*Significant at $5 \%$ by the method of "bootstrap" with 5000 simulations.

The significance of the effect of the treatments $(\mathrm{P}<0.01)$ (Table 3) showed the existence of variability between the parents, considering these 4 characters. This variability is essential for the determination of the genetic control of the characters under study, as well as increase in the chance of success in the extraction of superior lines from the segregating populations originated from the partial diallel crosses.

\begin{tabular}{|c|c|c|c|c|c|}
\hline \multirow[t]{2}{*}{ Source of variation } & \multirow[t]{2}{*}{ Degrees of freedom } & \multicolumn{4}{|c|}{ Mean square } \\
\hline & & PAG & $\mathrm{HD}$ & MPH & YIELD \\
\hline Treatments & 61 & $0.77 * *$ & $0.008^{* *}$ & $123.78 * *$ & $539,398.92^{* *}$ \\
\hline Residue & 122 & 0.16 & 0.001 & 15.52 & $100,898.58$ \\
\hline CV (\%) & & 16.79 & 5.34 & 9.73 & 9.05 \\
\hline Mean & & 2.42 & 0.58 & 40.51 & $3,509.87$ \\
\hline
\end{tabular}

**Significant at $1 \%$ of probability by the $\mathrm{F}$ test. $\mathrm{CV}=$ coefficient of variation.

The regression coefficients of $\mathrm{W}_{\mathrm{r}}$ as a function of $\mathrm{V}_{\mathrm{r}}$ and of $\mathrm{W}_{\mathrm{s}}$ as a function of $\mathrm{V}_{\mathrm{s}}$ were considered to be non-significant and statistically equal to one for plant architecture grade and hypocotyl diameter, showing that the dominant-additive model was adequate for the two groups of parents, aimed at studying the inheritance of these traits (Table 4). However, the dominant-additive model was not sufficient for mean plant height and grain yield.

\begin{tabular}{|c|c|c|c|c|c|c|c|c|c|c|}
\hline \multirow[t]{2}{*}{ Source of variation } & \multirow[t]{2}{*}{ d.f. (G1) } & \multicolumn{4}{|c|}{ Mean square (G1) } & \multirow[t]{2}{*}{ d.f. (G2) } & \multicolumn{4}{|c|}{ Mean square (G2) } \\
\hline & & HD & PAG & MPH & YIELD & & HD & PAG & MPH & YIELD \\
\hline Regression & 1 & $0.000001 * *$ & $0.0288 * *$ & $70.70^{\text {ns }}$ & $2,916,733,574.72^{\mathrm{ns}}$ & 1 & $0.000001^{*}$ & $0.0067 *$ & $6.38^{\mathrm{ns}}$ & $13,545,815,866.62^{\mathrm{ns}}$ \\
\hline Deviation & 6 & 0.000000 & 0.0013 & 41.41 & $830,518,392.17$ & 4 & 0.000000 & 0.0006 & 238.65 & $6,139,652,531.61$ \\
\hline Intercept & & 0.0005 & 0.0444 & 8.17 & $27,238.75$ & & 0.0007 & -0.0004 & 7.80 & $-29,152.54$ \\
\hline Angular coefficient (b) & & 1.2235 & 1.2018 & 0.39 & -0.49 & & 1.0016 & 0.8771 & -0.14 & 0.91 \\
\hline Value of $t\left(\mathrm{H}_{0}: \mathrm{b}=1\right)$ & & $0.888^{\mathrm{ns}}$ & $0.800^{\text {ns }}$ & $-2.07^{*}$ & $-5.74 *$ & & $0.006^{\text {ns }}$ & $-0.477^{\mathrm{ns}}$ & $-1.36^{*}$ & $-0.14^{\mathrm{ns}}$ \\
\hline
\end{tabular}


A sufficient dominant-additive model indicates that the presuppositions of genes with Mendelian inheritance, diploid species, homozygotic parents, absence of maternal effect, absence of multiple allelism, independent distribution of non-allelic genes between parents, and absence of epistasis are met (Hayman, 1954). Otherwise, the most common consequence has been the occurrence of epistasis in the genetic control of the character under study and of genes not independently distributed between parents (Cruz et al., 2004).

This last requirement is often not met when elite lines are studied, such as group 2 in this study, although, in this case, such lines were not selected based on the characters related to plant architecture. Thus, the non-sufficiency of the dominant-additive models for the study of inheritance of the characters mean plant height and grain yield may be due to the occurrence of epistasis in the genetic control of these characters. It must be emphasized that these characteristics are complex, as they are dependent on others.

\section{Genetic parameters}

The estimates of the genetic parameters for the traits plant architecture grade and hypocotyl diameter are shown in Table 5 . The components associated with the additive effects $\left[\mathrm{D}_{(1)}\right.$ and $\left.\mathrm{D}_{(2)}\right]$ were predominant in relation to those associated with the dominance effects $\left[\mathrm{H}_{1(1)}, \mathrm{H}_{1(2)}\right.$, $\mathrm{H}_{2}, \mathrm{H}_{2}$ and $\left.\mathrm{h}^{2}\right]$ for the two traits. This indicates that the additive fraction is the main responsible factor for the genetic control of plant architecture and hypocotyl diameter in the common bean. Similar results were obtained by Santos and Vencovsky (1986) and Teixeira et al. (1999).

The significance of the additive components $\left[\mathrm{D}_{(1)}\right.$ and $\left.\mathrm{D}_{(2)}\right]$ indicates the existence of genetic variability in the two groups of parents for the traits studied. To plant architecture grade, the estimate of $\mathrm{D}_{(1)}-\mathrm{D}_{(2)}$ was less than zero (-0.4204) (Table 5), demonstrating greater variability in group $2\left[\mathrm{D}_{(2)}>\mathrm{D}_{(1)}\right]$. This was an expected result, as these group lines were more divergent in plant architecture, and were chosen based on grain yield and appearance, without taking plant architecture into account. As for hypocotyl diameter, the difference between $\mathrm{D}_{(1)}$ and $\mathrm{D}_{(2)}$ was close to zero (0.0003), indicating that variability was similar for the two groups of parents.

The estimates of the ratios $\mathrm{H}_{2} / 4 \mathrm{H}_{1(2)}$ (group1) and $\mathrm{H}_{2} / 4 \mathrm{H}_{1(1)}$ (group 2) indicated the distribution of the alleles among the parents of each group (symmetry). The alleles show symmetric distribution when this ratio is close to 0.25 , and asymmetric distribution when close to zero. For plant architecture (group 1) and hypocotyl diameter (groups 1 and 2), the values were well below 0.25 , indicating that the alleles with favorable or unfavorable effects had asymmetric distribution in the parents. Such estimates were equal to $-0.07,0.10$, and 0.06 , respectively.

Only group 2, for plant architecture grade, displayed a high symmetry value (0.32). This estimate was probably biased, since the maximum parametric value expected was 0.25 . This result indicates that the trait plant architecture grade is much more complex than hypocotyl diameter. This greater complexity results from the large number of characters involved in the determination of plant architecture of the common bean. Besides, plant architecture grade is a less precise trait, compared to hypocotyl diameter. This lower precision was expected, since plant architecture grade attribution is subjective and arduous, requiring experienced professionals to obtain a more precise evaluation, while hypocotyl diameter is measured with a digital pachymeter, and is thus subject to much smaller errors. The variation coefficients of these characters (Table 3 ) also confirm these results. However, since the value estimated for symmetry was high $(0.32)$ and close to 0.25 , it can be inferred that the genes determining plant architecture grade are equally distributed in the parents of this group. 
Table 5. Estimates of the genetic parameters for the traits plant architecture grade (PAG) and hypocotyl diameter (HD) in the common bean.

\begin{tabular}{|c|c|c|c|c|c|c|}
\hline \multirow[t]{2}{*}{ Parameter } & \multicolumn{3}{|c|}{ PAG } & \multicolumn{3}{|c|}{ HD } \\
\hline & Estimate & Standard deviation & $t$ & Estimate & Standard deviation & $t$ \\
\hline$D_{1}{ }^{a}$ & 0.1435 & 0.0301 & $4.7713^{*}$ & 0.0047 & 0.0002 & $21.9975^{*}$ \\
\hline $\mathrm{D}_{2}^{\mathrm{a}}$ & 0.5639 & 0.0301 & $18.7488^{*}$ & 0.0044 & 0.0002 & $20.5549^{*}$ \\
\hline $\mathrm{F}_{1}$ & 0.7354 & 0.0877 & $8.3869^{*}$ & 0.0039 & 0.0006 & $6.2278^{*}$ \\
\hline $\mathrm{F}_{2}$ & 0.2576 & 0.0877 & $2.9371^{*}$ & 0.0018 & 0.0006 & $2.8594^{*}$ \\
\hline $\mathrm{F}_{3}$ & 0.8851 & 0.0877 & $10.0938^{*}$ & 0.0020 & 0.0006 & $3.1772 *$ \\
\hline $\mathrm{F}_{4}$ & 0.2356 & 0.0877 & $2.6871^{*}$ & 0.0052 & 0.0006 & $8.2615^{*}$ \\
\hline $\mathrm{F}_{5}$ & 0.4077 & 0.0877 & $4.6491^{*}$ & 0.0022 & 0.0006 & $3.4950^{*}$ \\
\hline $\mathrm{F}_{6}$ & 0.6522 & 0.0877 & $7.4381^{*}$ & 0.0000 & 0.0006 & -0.0005 \\
\hline $\mathrm{F}_{7}$ & 0.6854 & 0.0877 & $7.8162^{*}$ & 0.0022 & 0.0006 & $3.4314 *$ \\
\hline $\mathrm{F}_{8}$ & 0.7556 & 0.0877 & $8.6172^{*}$ & 0.0034 & 0.0006 & $5.4016^{*}$ \\
\hline $\mathrm{F}_{1}^{\prime}$ & 0.1194 & 0.0885 & 1.3481 & 0.0011 & 0.0006 & 1.7419 \\
\hline $\mathrm{F}_{2}^{\prime}$ & -0.2256 & 0.0885 & $-2.5473^{*}$ & 0.0034 & 0.0006 & $5.3385^{*}$ \\
\hline $\mathrm{F}_{3}^{\prime}$ & 0.0758 & 0.0885 & 0.8566 & 0.0040 & 0.0006 & $6.2377^{*}$ \\
\hline $\mathrm{F}_{4}^{\prime}$ & -0.2643 & 0.0885 & $-2.9846^{*}$ & 0.0025 & 0.0006 & $3.8999^{*}$ \\
\hline $\mathrm{F}_{5}^{\prime}$ & -0.0275 & 0.0885 & -0.3108 & 0.0021 & 0.0006 & $3.3154 *$ \\
\hline $\mathrm{F}_{6}^{\prime}$ & -0.1780 & 0.0885 & $-2.0107^{*}$ & -0.0008 & 0.0006 & -1.2702 \\
\hline $\mathrm{H}_{1(1)}{ }^{\mathrm{b}}$ & -0.0222 & 0.1190 & -0.1862 & 0.0007 & 0.0009 & 0.8594 \\
\hline $\mathrm{H}_{1(2)}{ }^{b}$ & 0.1040 & 0.1165 & 0.8925 & 0.0004 & 0.0008 & 0.5223 \\
\hline $\mathrm{H}_{21}$ & -0.0706 & 0.1203 & -0.5868 & -0.0001 & 0.0009 & -0.1580 \\
\hline $\mathrm{H}_{22}$ & -0.0011 & 0.1203 & -0.0090 & 0.0001 & 0.0009 & 0.1712 \\
\hline $\mathrm{H}_{23}$ & -0.0820 & 0.1203 & -0.6820 & 0.0000 & 0.0009 & 0.0196 \\
\hline $\mathrm{H}_{24}$ & 0.0184 & 0.1203 & 0.1526 & 0.0003 & 0.0009 & 0.3730 \\
\hline $\mathrm{H}_{25}$ & 0.0568 & 0.1203 & 0.4721 & 0.0000 & 0.0009 & -0.0044 \\
\hline $\mathrm{H}_{26}$ & -0.0775 & 0.1203 & -0.6445 & 0.0002 & 0.0009 & 0.2262 \\
\hline $\mathrm{H}_{27}$ & -0.0099 & 0.1203 & -0.0823 & 0.0008 & 0.0009 & 0.9261 \\
\hline $\mathrm{H}_{28}$ & -0.0663 & 0.1203 & -0.5513 & 0.0001 & 0.0009 & 0.1129 \\
\hline $\mathrm{H}_{2^{\prime} 1}$ & -0.0289 & 0.1193 & -0.2420 & 0.0001 & 0.0009 & 0.1556 \\
\hline $\mathrm{H}_{22}$ & -0.0248 & 0.1193 & -0.2083 & 0.0001 & 0.0009 & 0.0679 \\
\hline $\mathrm{H}_{2^{\prime 3}}$ & -0.0314 & 0.1193 & -0.2635 & -0.0001 & 0.0009 & -0.0937 \\
\hline $\mathrm{H}_{24}$ & -0.0349 & 0.1193 & -0.2924 & 0.0005 & 0.0009 & 0.5556 \\
\hline $\mathrm{H}_{2,5}$ & 0.0095 & 0.1193 & 0.0800 & 0.0000 & 0.0009 & 0.0355 \\
\hline $\mathrm{H}_{2^{\prime} 6}$ & -0.0554 & 0.1193 & -0.4643 & 0.0005 & 0.0009 & 0.5350 \\
\hline$h^{2 b}$ & -0.0201 & 0.0854 & -0.2358 & 0.0000 & 0.0006 & -0.0736 \\
\hline$\varepsilon$ & 0.0549 & 0.0213 & $2.5811^{*}$ & 0.0003 & 0.0002 & $2.1138^{*}$ \\
\hline Medium F & 0.5768 & 0.0673 & $8.5769^{*}$ & 0.0026 & 0.0005 & $5.3544 *$ \\
\hline Medium F' & -0.0834 & 0.0695 & -1.2001 & 0.0020 & 0.0005 & $4.0927^{*}$ \\
\hline Medium $\mathrm{H}_{2}$ & -0.0284 & 0.0797 & -0.3569 & 0.0002 & 0.0006 & 0.3139 \\
\hline
\end{tabular}

${ }^{\mathrm{a}}$ Components associated with the additive effects; ${ }^{\mathrm{b}}$ components associated with the dominance effects. *Significant according to Singh and Chaudhary (1979).

The components $\mathrm{H}_{1(1)}$ and $\mathrm{H}_{1(2)}$ for the two characteristics were non-significant and close to zero, indicating the absence of dominance in the genetic control of these characters. According to Viana et al. (1999), when variability occurs between the parents of a group, component $\mathrm{H}_{1}$ of this group will be null in the absence of dominance and positive in the presence of significant deviations from dominance, in the genetic control of the character under study. Other indicatives of absence of dominance in the genetic control of the traits plant architecture grade and hypocotyl diameter are the non-significant estimates of the components $\mathrm{H}_{2}, \mathrm{H}_{2}$, and medium $\mathrm{H}_{2}$ (Table 5). 
In the presence of dominance, the $\mathrm{F}$ estimates of the parents of one group allow ordering them according to the number of dominant genes not fixed on the lines of the other group (Viana et al., 1999). Thus, in the absence of dominance, as detected in this study, the F component is not a reliable statistic in establishing the order of the parents related to the existing number of dominant genes. This fact can be visualized by the contradiction between the order established for plant architecture grade of group 1 parents (IPR Uirapuru, A525, BRS Valente, A170, A805, CNFC 9466, BRS Supremo, and BRS Horizonte) and that established for hypocotyl diameter for these same parents (BRS Horizonte, BRS Valente, A525, CNFC 9466, A170, IPR Uirapuru, and BRS Supremo) (Table 5). Because of the high genetic correlation $(-0.80)$ between the traits plant architecture grade and hypocotyl diameter, the classification of the parents for number of their dominant genes is expected to be the same for these two traits. It must also be stressed that the line BRS Horizonte, classified by $\mathrm{F}$ values as having a higher number of dominant genes, showed a smaller mean hypocotyl diameter (Table 6). This result is another indication that $\mathrm{F}$ values, in the absence of dominance, do not have a direct relationship with frequency of the dominant genes.

Table 6. Mean of plant architecture grade (PAG), hypocotyl diameter (HD), mean plant height (MPH), and grain yield (YIELD) obtained in the evaluation of the 14 parents and 48 hybrids of the common bean.

\begin{tabular}{|c|c|c|c|c|}
\hline Genotypes & PAG & $\mathrm{HD}(\mathrm{cm})$ & $\mathrm{MPH}(\mathrm{cm})$ & YIELD (kg/ha) \\
\hline BRS Valente & 2.500 & 0.584 & 42 & 3444 \\
\hline BRS Supremo & 1.667 & 0.646 & 49 & 3620 \\
\hline IPR Uirapuru & 2.000 & 0.689 & 51 & 3380 \\
\hline BRS Horizonte & 2.000 & 0.518 & 41 & 2724 \\
\hline CNFC9466 & 2.000 & 0.604 & 46 & 3220 \\
\hline A805 & 1.500 & 0.648 & 50 & 2539 \\
\hline A170 & 2.000 & 0.594 & 53 & 3276 \\
\hline A525 & 1.000 & 0.752 & 71 & 2007 \\
\hline $\mathrm{G}_{1}$ mean & 1.833 & 0.630 & 50 & 3026 \\
\hline VC6 & 1.833 & 0.623 & 46 & 2741 \\
\hline BRS MG Majestoso & 3.167 & 0.531 & 39 & 3304 \\
\hline Madrepérola & 4.167 & 0.423 & 28 & 3344 \\
\hline L1 & 2.667 & 0.589 & 38 & 3322 \\
\hline L2 & 3.500 & 0.516 & 38 & 2983 \\
\hline L3 & 3.000 & 0.553 & 36 & 3115 \\
\hline $\mathrm{G}_{2}$ mean & 3.056 & 0.539 & 38 & 3135 \\
\hline Hybrids mean & 2.434 & 0.580 & 39 & 3637 \\
\hline Parents mean & 2.445 & 0.585 & 44 & 3081 \\
\hline
\end{tabular}

The mean $\mathrm{F}$ value in a group of parents is indicative of the relative frequencies of the dominant and recessive genes involved in the control of the character in question of each group of lines that are not fixed in the opposing group. For plant architecture grade, the mean F estimate was found to be positive and significant for group 1, showing that the dominant genes of this group, not fixed on group 2 lines, are more frequent than the recessive ones (Table 5). In group 2, the mean F' estimate was close to zero and non-significant, indicating that the dominant genes that determine plant architecture in this group and are not fixed on group 1 lines, are equally distributed among the lines of this group.

For hypocotyl diameter, the two groups exhibited positive mean $\mathrm{F}$ and $\mathrm{F}^{\prime}$ estimates (Table 5), indicating that the two groups of parents have higher frequency of dominant genes not fixed on the opposing group. The information obtained from the $\mathrm{F}$ and $\mathrm{F}^{\prime}$ mean values is corroborated by the information provided by the symmetry values. 
It must be pointed out that the information regarding the $\mathrm{F}$ values refers to different genes present in each line group. Since the absence of dominance was observed for both traits analyzed, it can be inferred that the hybrids resulting from the crosses between the lines of the two groups of parents will not exhibit heterosis. However, the lines of the two groups have genes that complement and that will allow transgressive segregation in segregating populations derived from $\mathrm{F}_{1}$ hybrids, for the traits related to plant architecture of the common bean. Since group 1 lines were more erect than those of group 2 (Table 1), it was concluded that the dominant genes act by reducing plant architecture grade and increasing the hypocotyl diameter, contributing to improvement of plant architecture of the common bean. The lines of group 1 had a higher proportion of dominant genes for the traits plant architecture grade and hypocotyl diameter, and thus, they showed a high potential as parents for breeding programs aimed at improving plant architecture of the common bean.

The broad-sense heritability estimate was higher for hypocotyl diameter $(0.81)$ than for plant architecture grade (0.60), showing that the latter is more complex than the former. The reason is that many characters, such as growth habit, internode number and length, hypocotyl diameter, first pod insertion height, number of branches, plant height, branch insertion angle, pod distribution, and stay green presence, affect plant architecture (Leakey, 1988; Acqaah et al., 1991; Kornegay et al., 1992; Brothers and Kelly, 1993; Teixeira et al., 1999; Aguiar et al., 2000). In the absence of dominance, as reported by Moreto et al. (2007), one can infer that strict-sense heritability may be of a magnitude close to broad-sense heritability. Moreover, the genotypic variance fraction was predominantly of additive nature for both characters.

Determination of the genetic control of the characters may help breeders carry out a more efficient breeding program, such as in the case of autogamous plants, when choosing potential parents and especially when determining the endogamous generation more appropriate for bulk opening and more efficient selection strategies. Based on the results obtained, it was concluded that the selection of more erect plants can be practiced in early generations, since the traits plant architecture grade and hypocotyl diameter have a predominance of additive effects.

When the bulks are open still at initial generations, such as $\mathrm{F}_{2}, 50 \%$ of the genotypic variation is expected to occur between plants within the $\mathrm{F}_{2: 3}$ families (Vencovsky and Barriga, 1992). Thus, hypocotyl diameter has a greater potential to be used in the selection of more erect plants, by considering selection between and within families, or by combined or phenotypic recurrent selection. This is because diameter measurements were made using individual plants within plots and showed a higher accuracy [heritability $=0.81$ ] and precision [coefficient of variation $=5.34 \%$ ] when evaluated.

It must be emphasized that the trait hypocotyl diameter can also be used in selection, rendering this process more efficient. Thus, it is suggested that family derivation be conducted from $\mathrm{F}_{2}$ plants showing larger hypocotyl diameter. The progeny are expected to display greater potential in the selection of erect plants.

\section{ACKNOWLEDGMENTS}

Research supported by Conselho Nacional de Desenvolvimento Científico e Tecnológico (CNPq), Coordenação de Aperfeiçoamento de Pessoal de Nível Superior (CAPES), and Fundação de Amparo à Pesquisa do Estado de Minas Gerais (FAPEMIG) in relation to the Common Bean Breeding Program of the Universidade Federal de Viçosa, Brazil. 


\section{REFERENCES}

Acquaah G, Adams MW and Kelly JD (1991). Identification of effective indicators of erect plant architecture in dry bean. Crop Sci. 31: 261-264.

Acquaah G, Adams MW and Kelly JD (1992). A factor analysis of plant variables associated with architecture and seed size in dry bean. Euphytica 60: 171-177.

Adams MW (1973). Plant Architecture and Physiological Efficiency. In: Centro Internacional de Agricultura Tropical. Potentials of field beans and other food legumes in Latin America, Cali, 226-278.

Adams MW (1982). Plant architecture and yield breeding. Iowa State J. Res. 56: 225-254.

Aguiar AM, Ramalho MAP and Marques Júnior OG (2000). Controle genético do stay green no feijoeiro (Phaseolus vulgaris L.). Rev. Ceres 47: 155-167.

Basset MJ (2004). List of genes - Phaseolus vulgaris L. Ann. Rep. Bean Improv. Coop. 47: 1-24.

Beattie AD, Larsen J, Michaels TE and Pauls KP (2003). Mapping quantitative trait loci for a common bean (Phaseolus vulgaris L.) ideotype. Genome 46: 411-422.

Brothers ME and Kelly JD (1993). Interrelationship of plant architecture and yield components in the pinto bean ideotype. Crop Sci. 33: 1234-1238.

Collicchio E, Ramalho MAP and Abreu AFB (1997). Associação entre o porte da planta do feijoeiro e o tamanho dos grãos. Pesq. Agropec. Bras. 32: 297-304.

Cruz CD (2006). Programa Genes: Biometria. Universidade Federal de Viçosa, Viçosa.

Cruz CD, Regazzi AJ and Carneiro PCS (2004). Modelos Biométricos Aplicados ao Melhoramento Genético. 3rd edn. Universidade Federal de Viçosa, Viçosa.

Hayman BI (1954). The theory and analysis of diallel crosses. Genetics 39: 789-809.

Izquierdo JA and Hosfield GL (1983). The relationship of seed filling to yield among dry beans with differing architectural forms. J. Am. Soc. Hortic. Sci. 108: 106-111.

Kelly JD and Adams MW (1987). Phenotypic recurrent selection in ideotype breeding of pinto beans. Euphytica 36: 69-80. Kornegay J, White JW and Cruz OO (1992). Growth habit and gene pool effects on inheritance of yield in common bean. Euphytica 62: 171-180.

Leakey CLA (1988). Genotypic and Phenotypic Markers in Common Bean. In: Genetic Resources of Phaseolus beans: Their Maintenance, Domestication, Evolution, and Utilization (Gepts P, ed.). Kluwer Academic Publishers, Dordrecht, 245-327.

Moreto AL, Ramalho MAP, Nunes JAR and Abreu AFB (2007). Estimação dos componentes da variância fenotípica em feijoeiro utilizando o método genealógico. Cienc. Agrotec. 31: 1035-1042.

Nienhuis J and Singh SP (1986). Combining ability analyses and relationships among yield, yield components, and architectural traits in dry bean. Crop Sci. 26: 21-27.

Peternelli LA, Borém A and Carneiro JES (2009). Hibridação em Feijão. In: Hibridação Artificial de Plantas (Borém A, ed.). Universidade Federal de Viçosa, Viçosa, 269-294.

Ragagnin VA, Souza TLPO, Sanglard DA, Arruda KMA, et al. (2009). Development and agronomic performance of common bean lines simultaneously resistant to anthracnose, angular leaf spot and rust. Plant Breed. 128: 156-163.

Santos JB and Vencovsky R (1986). Controle genético de alguns componentes do porte da planta em feijoeiro. Pesq. Agropec. Bras. 21: 957-963.

Silva CA, Abreu AFB and Ramalho MAP (2009). Associação entre arquitetura de planta e produtividade de grãos em progênies de feijoeiro de porte ereto e prostrado. Pesq. Agropec. Bras. 44: 1647-1652.

Singh RK and Chaudhary BD (1979). Biometrical Methods in Quantitative Genetic Analysis. Kalyani, New Delhi.

Teixeira FF, Ramalho MAP and Abreu AFB (1999). Genetic control of plant architecture in the common bean (Phaseolus vulgaris L.). Genet. Mol. Biol. 22: 577-582.

Vencovsky R and Barriga P (1992). Genética Biométrica no Fitomelhoramento. Sociedade Brasileira de Genética, Ribeirão Preto.

Viana JMS, Cruz CD and Cardoso AA (1999). Theory and analysis of partial diallel crosses. Genet. Mol. Biol. 22: 591-599. 